九州大学学術情報リポジトリ

Kyushu University Institutional Repository

\title{
HAUSMANNITE FROM THE IOI MINE, SHIGA PREFECTURE， JAPAN
}

Shirozu, Haruo

Faculty of Sciences, Kyushu University

https://doi.org/10.5109/1524101

出版情報：九州大學理學部紀要：Series D, Geology. 3 (2)，pp.71-76，1949-11-10. Faculty of Science, Kyushu University バージョン:

権利関係: 


\title{
HAUSMANNITE FROM THE IOI MINE, SHIGA PREFECTURE, JAPAN
}

\author{
By
}

\section{Haruo SHIRozU}

(Received April, 20th, 1949)

\section{Introduction}

The Ioi $^{*}$. Mine is situated near the lake of Biwa in Shiga Prefecture, Japan, and consists of workings on two (east and west) vein-formed manganese deposits. These deposits have been formed along a contact plane between quartzite and sandyslate in the Palaeozoic formation. The western ore body which is the representative of Prof. T. Yoshimura's Ioi Type deposit, has produced large quantities of manganese dioxide ore during those ten years.

The author has engaged under the guidance of Prof. YosHIMURA in geological and mineralogical studies of the Ioi deposit and found that in the eastern ore body there occur hausmannite ${ }^{(1)}$ and other interesting maganese minerals. The following is a brief report of the hausmannite and its associated minerals.

The author's sincere thanks are due to Prof. Yoshimura and Lect. Y. Окамото for their kind guidance, and also to Mr. T. OKABE, the owner of the Ioi Mine, for his personal courtesy added to the work.

\section{Occurrence and General Properties}

Hausmannite occurs abundantly as fine-grained compact masses or layers, accompanied intimately by tephroite, rhodochrosite and manganosite (Pl. I, Fig. 1, Fig. 2). The size of grains are $0.5^{\circ} \mathrm{mm}$ accross at the largest. Under the microscope, hausmannite and

1) Dr. M. Ishibashi wrote on hausmannite from Ōmatumae Mine, Hokkaidō. M. Ishibashi: Journ. Fac: Sci., Hakkaidō Inniversity, Ser. IV, Vol. 8. 1-4 (1948).

*五百井 
tephroite are euhedral or subhedral and rhodochrosite fills up their interstices. Thin sections of hausmannite are generally opaque, but some slices are translucent with deep reddish brown color. Anisotropic. Color black, streak brown. Although the crystal forms are not seen by the naked eye, they often show hexagonal outlines under the microscope (Pl. 1, Fig. 1) Perhaps they may be octahedral in habit.

Specific gravity; $\mathrm{d}_{4}^{26}=4.86$. Hardness; $\mathrm{H}=5$. Soluble in hot concentrated hydrochloric acid, but insoluble in hot dilute hydrochloric acid. Insoluble in cold acid.

\section{Chemical Composition}

Crystal fragments of hausmannite were picked up and the admixtures of tephroite and rhodochrosite were dissolved away in hot dilute hydrochloric acid. The results of the chemical analysis are given in Table I, No. 2, being compared with other known analyses.

Table I. Chemical composition of hausmannite.

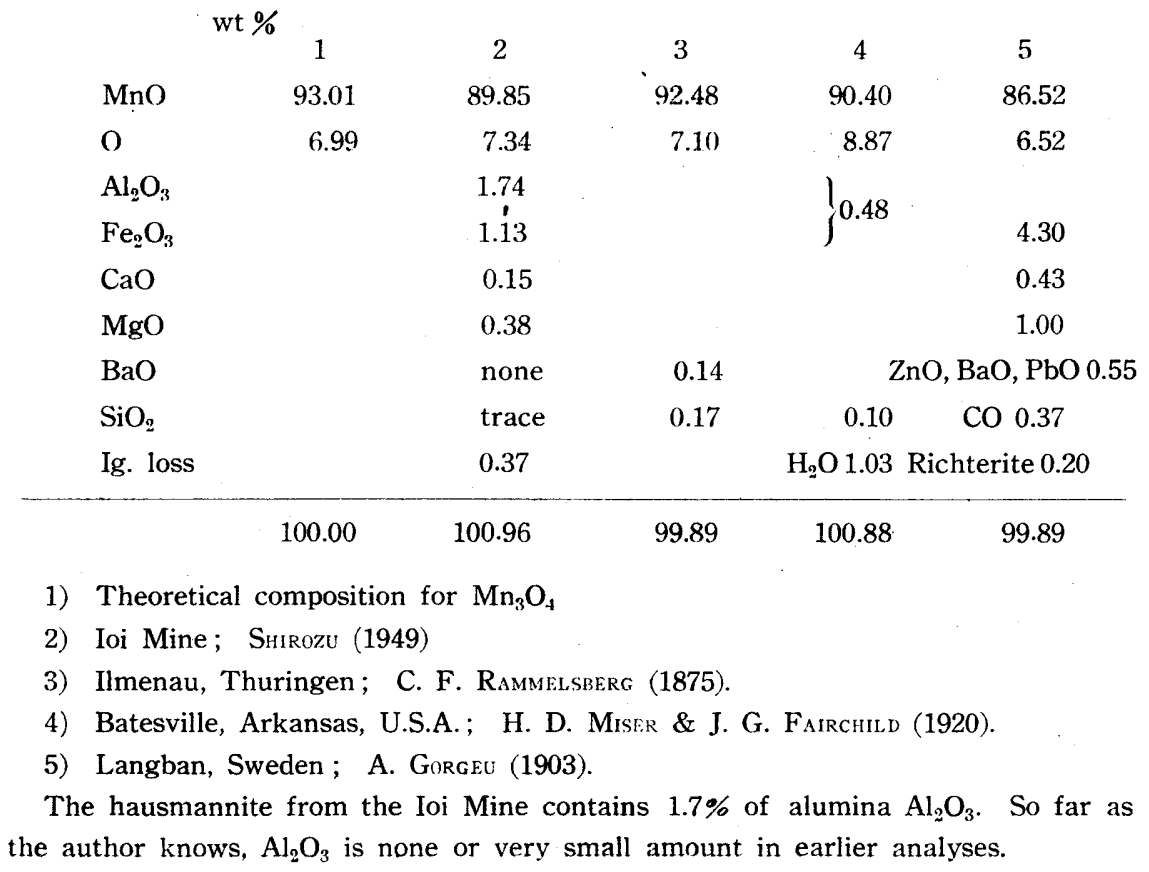




\section{X-Ray Powder Photographs}

X-ray powder photographs of this mineral were taken at the research laboratory of Kurosaki Fire-brick Manufacturing Company and the author's sincere thanks are due to the kind service of Mr. Y. ShIRAĪshI. The radius of the camera is $30.6 \mathrm{~mm}$, with Feanticathode and no filter. The distance of atomic planes $\mathrm{hkl}$ and intensity of lines, calculated and measured on the photograph, are given in Table 2, No. 1 .

Here also are given those values on "earthy hausmannite" (No. 2), read on powder photographs which were taken under the same condition.

Also the data on artificial $\mathrm{Mn}_{3} \mathrm{O}_{4}$ (No. 3), and those on the hausmannite in the paper of W. S. SMITHERINGALE (No. 4). These four coincide satisfactorily with one another.

Table 2. Measurements of powder photograph films of hausmannite.

\begin{tabular}{|c|c|c|c|c|c|c|c|}
\hline \multicolumn{2}{|c|}{$\begin{array}{c}\text { No. } 1 \\
\text { Hausmannite } \\
\text { (Ioi Mine) }\end{array}$} & \multicolumn{2}{|c|}{$\begin{array}{c}\text { No. } 2 \\
\begin{array}{c}\text { Earthy hausmannite } \\
\text { (Ioi Mine) }\end{array}\end{array}$} & \multicolumn{2}{|c|}{$\begin{array}{c}\text { No. } 3 \\
\text { Mn }_{3} \mathrm{O}_{4} \\
\text { (Artificial) }\end{array}$} & \multicolumn{2}{|c|}{$\begin{array}{c}\text { No. } 4 \\
\text { Hausmannite } \\
\text { (Cape Breton Is U.S.A.) }\end{array}$} \\
\hline d & I & $\mathrm{d}$ & I & d & I & $\mathrm{d}$ & I \\
\hline 4.95 & WW & & & 4.92 & 0.20 & & \\
\hline \multirow[t]{3}{*}{3.09} & $\mathbf{W}$ & 3.08 & W & 3.08 & 0.31 & 3.07 & $\mathrm{~m}$ \\
\hline & & & & 2.87 & 0.08 & 2.85 & v.w. \\
\hline & & $(2.85$ & $W)^{*}$ & & & & \\
\hline \multirow[t]{2}{*}{2.77} & S & 2.77 & $\mathbf{M}^{+}$ & 2.75 & 0.63 & 2.73 & $\mathrm{~h}$ \\
\hline & & & & 2.56 & 0.08 & & \\
\hline 2.50 & SS & 2.49 & $\mathrm{~S}^{+}$ & 2.48 & 1.00 & 2.45 & $\mathrm{~h}$ \\
\hline \multirow[t]{3}{*}{2.36} & w & 2.37 & W & 2.36 & 0.13 & 2.33 & w \\
\hline & & & & 2.22 & 0.31 & & \\
\hline & & & & & & 2.125 & e.w. \\
\hline \multirow[t]{2}{*}{2.04} & $\mathbf{M}^{-}$ & 2.04 & W & 2.03 & 0.15 & 2.025 & $\mathbf{w}^{+}$ \\
\hline & & & & & & 1.815 & $?$ \\
\hline \multirow[t]{3}{*}{1.79} & $\mathrm{~W}$ & 1.80 & $\mathrm{~W}$ & 1.79 & 0.18 & 1.77 & $\mathbf{w}$ \\
\hline & & (1.77 & $\mathrm{WW})^{*}$ & & & & \\
\hline & & & & & & 1.725 & e.w. \\
\hline \multirow[t]{2}{*}{1.71} & W & 1.71 & wW & 1.70 & 0.05 & 1.685 & $\mathbf{w}$ \\
\hline & & & & 1.64 & 0.05 & 1.625 & $\mathbf{w}$ \\
\hline
\end{tabular}




\begin{tabular}{|c|c|c|c|c|c|c|c|}
\hline 1.58 & $\mathrm{M}$ & 1.58 & $\mathbf{M}$ & 1.57 & 0.50 & 1.56 & $\mathrm{~m}$ \\
\hline \multirow[t]{2}{*}{1.54} & $\mathrm{~S}$ & 1.54 & $S$ & 1.54 & 0.50 & 1.53 & $\mathrm{~h}-$ \\
\hline & & & & 1.466 & 0.03 & & \\
\hline \multirow[t]{4}{*}{1.45} & W & 1.44 & W & 1.438 & 0.18 & 1.427 & $\mathrm{w}$ \\
\hline & & & & 1.384 & 0.04 & 1.375 & e.w. \\
\hline & & & & 1.340 & 0.08 & $1.33^{+}$ & e.w. \\
\hline & & & & 1.300 & 0.03 & 1.30 & e.w.? \\
\hline \multirow[t]{5}{*}{1.28} & WW & & & 1.277 & 0.13 & 1.265 & v.w. \\
\hline & & & & 1.237 & $0.04 \mathrm{~B}$ & 1.235 & e.w. \\
\hline & & & & & & 1.224 & e.w.? \\
\hline & & & & 1.192 & $0.05 \mathrm{~B}$ & 1.185 & v.w. \\
\hline & & & & & & 1.14 & . ? \\
\hline 1.12 & WW & & & 1.123 & 0.04 & 1.115 & v.w. \\
\hline \multirow[t]{3}{*}{1.08} & WW & & & & & 1.076 & v.w. \\
\hline & & & & & & 1.055 & e.w.? \\
\hline & & & & & & $\begin{array}{l}1.02 \\
\text { tted tho }\end{array}$ & $\begin{array}{l}\text { v.w. (wide } \\
\text { e below } 1.0 \text { ) }\end{array}$ \\
\hline
\end{tabular}

\section{Earthy Hausmannite}

In the high grade ores of the Ioi mine, particularly in the light pink rhodochrosite ore, we find brown spots of soft earthy manganeseoxide mineral. Chemical analysis shows $60 \%$ of manganese $(\mathrm{Mn})$ in this mineral. Its color resembles closely to the streak color of hausmannite, and the X-ray powder photographs coincide also with those of hausmannite as shown in Table 2 , No. 2. Accordingly, it is highly probable that the brown-colored earthy hausmannite has the same crystalline structure as that of the black hausmannite.

The grain size of the earthy hausmannite, however, being extremely fine, its color differs so much from that of the crystal.

\section{Genesis}

The eastern part of the Ioi deposit is a complicated bedded vein, consisting mainly of hausmannite, earthy hausmannite, rhodochrosite, tephroite, rhodonite, alabandite, spessartine and mangan- 
tremolite-actinolite. Besides them we can find in this deposit such numerous minerals as follows:

Pyrrhotite, arsenopyrite, marcasite (?), pyrite, manganosite, quartz, chalcedony, opal, noble opal, manganbrucite (?), pyrochroite manganite(?), manganese dioxide ore, galaxite, mangancalcite, barite, apatite, adularia, alleghanyite, manganhedenbergite, dannemorite, manganphlogopite, chlorite, penwithite. Some details concerning these minerals will be briefly described in the next section.

\section{Associated Minerals}

(a) Alabandite. Alabandite occurs widespread in rich ores.

Generally fine grains and no distinct crystal forms.

In a drusy cavity, however, were found some fine crystals, about $1 \mathrm{~mm}$ in diameter, as shown in Pl. 1, Fig. 3.

The dominant form is (100) and smaller forms are (i11) and (111)

(b) Manganbrucite (?). This mineral is often seen under the microscope in a slice of a fragile brownish gray manganese carbonate ore (Ṕl. 1, Fig. 4). Sometimes it occurs as small veinlets in the carbonate ore. This mineral is often found as micaceous platy crystals (Pl. II, Fig. 1). They need further research.

(c) Pyrochroite (?). Under the microscope this mineral is found as films surrounding a crystal of manganosite as presented in Pl. II, Fig. 2. Fibrous aggregate, brown on the outer side and pale yellow on the inner side, and not pleochroic. Owing to the lack of pleochroism it is uncertain whether this mineral can be identified exactly with pyrochroite.

(d) Galaxite. Galaxite occurs with tephroite or alleghanyite as fine grains, $0.1 \mathrm{~mm}$ in diameter. Color beautiful brownish yellow (Pl. II, Fig. 3)

(e) Alleghanyite. Alleghanyite resembles tephroite under the microscope, but can be distinguished from it by its characteristic polysynthetic twinning.

(f) Dannemorite. Dannemorite occurs usually with pyrrhotite and spessartine (Pl. II, Fig. 4). Sometimes it is found in the rhodochrosite ore with spessartine, and also as parallel fibrous aggregates filling crevices. 


\section{Explanation of the Plates}

\section{Plate I.}

Fig. 1. Photomicrograph of crystals of hausmannite (black), with tephroite (gray) and rhodochrosite (white). Parallel - nicols, $\times 30$.

Fig. 2. Hausmannite (black) and manganosite (gray).

The white portion is rhodochrosite. Parallel nicols, $\times 30$.

Fig. 3. Alabandite crystals. $\times 24$.

Fig. 4. Manganbrucite (?) (in the center) in the manganese carbonate ore (gray) Parallel nicols, $\times 95$.

\section{Plate II}

Fig. 1. Leaflets of manganbrucite crystals (?). $\times 24$.

Fig. 2. A drusy cavity full of fibrous pyrochroite (?). The innermost gray portion is manganosite. Parallel nicols, $\times 70$.

Fig. 3. Galaxite crystals (gray) in a tephroite mass. Parallel nicols, $\times 100$.

Fig. 4. Fibrous crystals of dannemorite (white) accompanied by pyrrhotite (black) embedded in a matrix of dannemorite and spessartine.

Parallel nicols, $\times 100$. 
Plate I
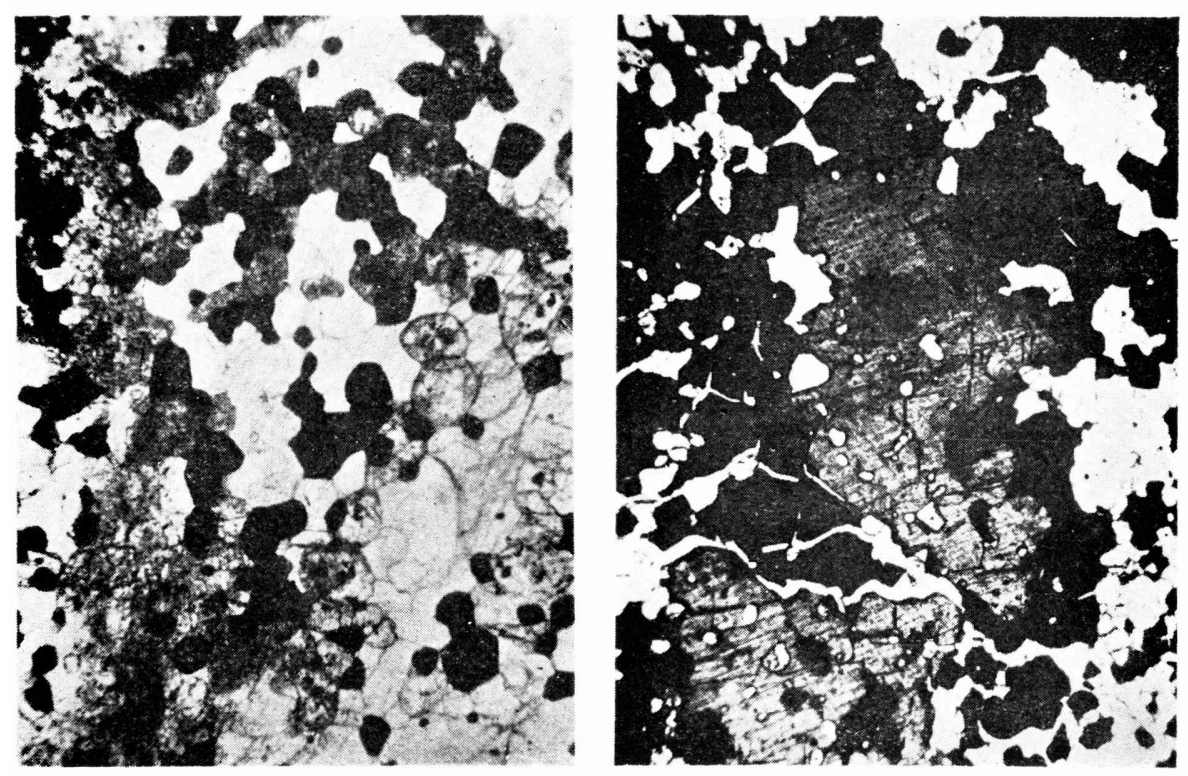

1
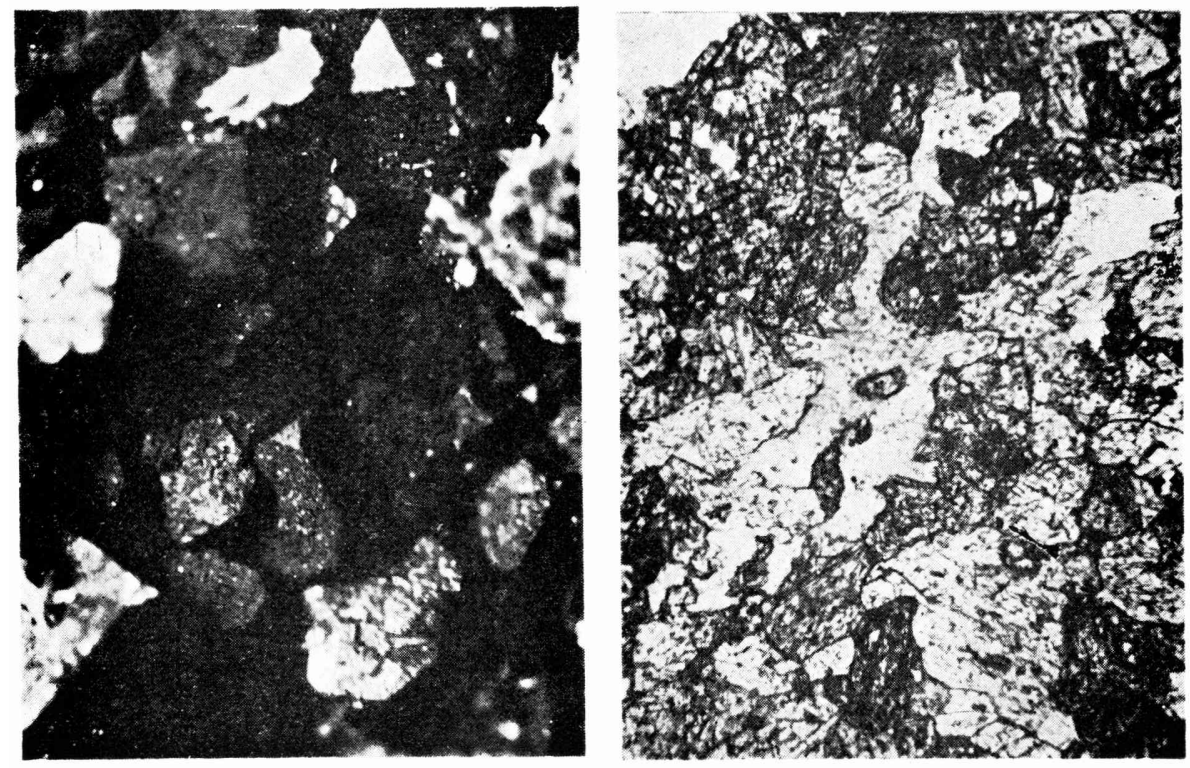

3 
Plate II

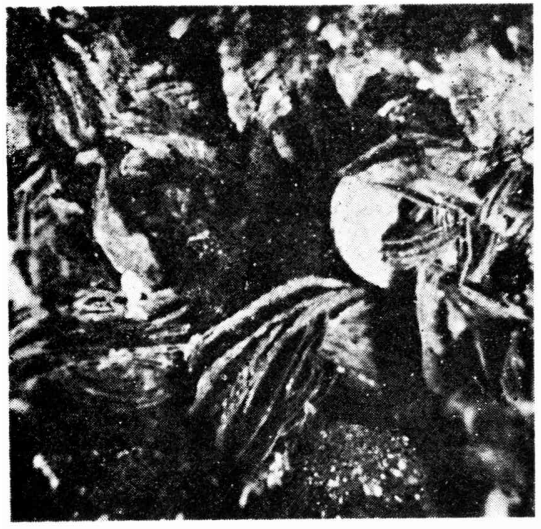

1

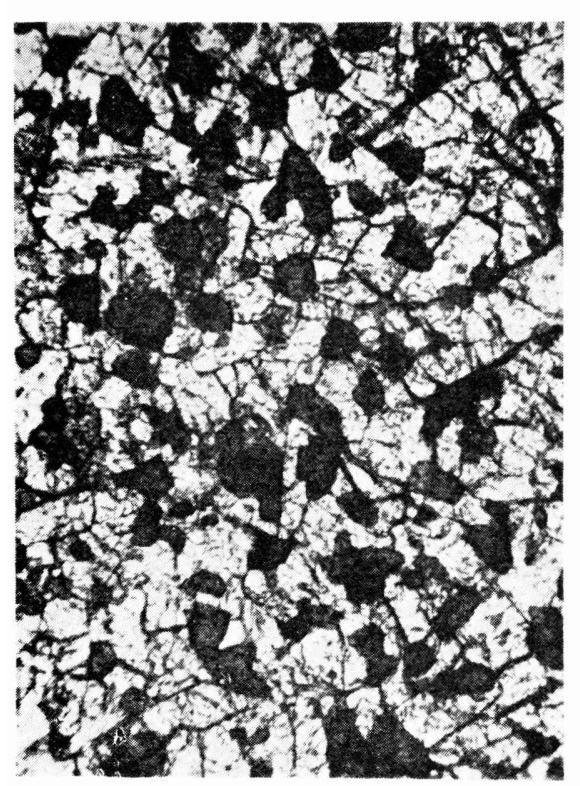

3

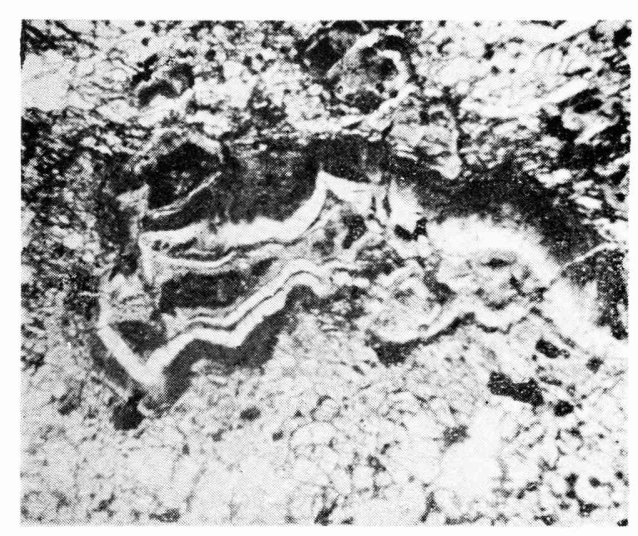

2

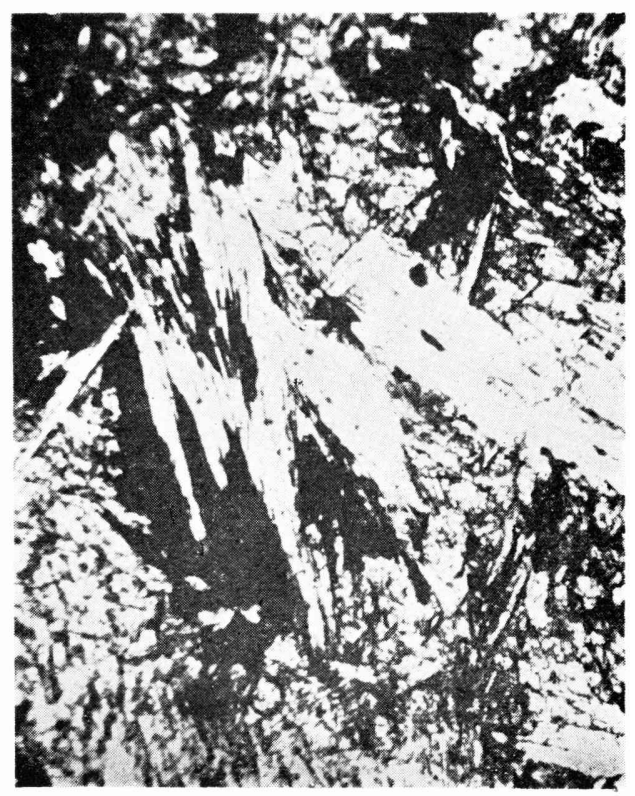

